\title{
Movie Consumption Related Trends and Countertrends In Consumer Behavior
}

https://doi.org/10.21272/sec.5(1).79-88.2021

Horváth Ádám, ORCID: https://orcid.org/0000-0003-4276-7069

Assistant Lecturer, Hungarian University of Agriculture and Life Sciences, Hungary

Gyenge Balázs, ORCID: https://orcid.org/0000-0001-8836-5992

Associate Professor, Hungarian University of Agriculture and Life Sciences, Hungary

\begin{abstract}
This paper aims to collect and study the various trends related to cultural consumption, more specifically behaviors reflecting in movie related consumption and choice (influencing both the habits of movie consumption and the related decision making). The paper summarizes and explores these trends from all major levels: the long term scaling 'megatrends' which appear on a global scale (and have major, interconnecting effects that may be perceived over a longer time period); the lower timescale, albeit more relevant 'trends' (which already stars to influence and merge into the everyday life of consumers) and their so-called 'countertrends' that might appear after reaching a certain threshold (along with certain previous trends' reemergence), and the 'latest trends' where even yearly changes and shifts could be shaping the near future (even before affecting the majority of societies).

The main purpose of the study is to systemize the literary sources and approaches to trends from the viewpoint of cultural consumption, through the format of literature study, with the focus point and relevance of this compilation being the movie- and movie related consumption.

The paper is carried out under the logical structure of exploring trends and their realization in movie consumption, examining both the generally accepted megatrends (such as the effects of technological progress or the changing pace of life) and also such unique phenomena as movie related aspects of comfort orientation, experiences deemed evident by the consumers, movie induced tourism (due to the popularity of filming locations), or even trends related to movie genres and their popularity. Additionally, the study also seeks to find out how certain trends may elicit their own countertrends through strengthening to the point where the opposite effects start to emerge as well. The results of the study can be useful for marketers to have a better grasp on the movie industry trends and especially for researchers, as it provides an important opportunity to better understand movie consumption and behavior of audiences, which may follow larger overlapping trends.
\end{abstract}

Keywords: movie consumption, consumer behavior, cultural marketing, trends, countertrends, megatrends.

JEL Classification: M31, M37.

Cite as: Horváth, A., Balázs, G. (2021). Movie Consumption Related Trends And Countertrends In Consumer Behavior. SocioEconomic Challenges, 5(1), 79-88. https://doi.org/10.21272/sec.5(1).79-88.2021.

Received: 03.02.2021

Accepted: 12.03 .2021

Published: 30.03 .2021

Copyright: (C) 2021 by the authors. Licensee Sumy State University, Ukraine. This article is an open access article distributed under the terms and conditions of the Creative Commons Attribution (CC BY) license (https:// creativecommons.org/licenses/by/4.0/).

\section{Introduction}

When exploring trends, we can differentiate with three levels according to Töröcsik (2011), where each has different degree of complexity and timescale. The widest range is represented by the so-called 'megatrends' (or base-trends), these are such long-term, 10 to 15 year spread global phenomena, which have unavoidable effects 
on a society. While 'trends' are considered more current, they generally represent a shorter range of 3 to 5 years, while their ever increasing importance already starting to build into the consumer behaviors of many, affecting their purchase decisions and habits. These trends, after reaching a certain threshold, may invoke their own 'countertrends' (following the dual nature of humanity) and later even the so-called 'again-trends' might emerge (which reinterpret the previously important trends that have faded for a while). The third level is represented by the 'latest trends', where even the annual shifts of emphasis may be observed, which point out what phenomena will shape the near future.

\section{Methodology}

Using the basis point of the differently time scaled trends we highlighted in the introduction, we have explored the various movie consumption, and movie choice behavior related (as in movie and other related consumption and decision making) trends, while also accounting for their emerging opposing phenomena, the countertrends.

The main structure of the paper was created under the logic of moving from the more general megatrends and current trends (while still having the focus point on movie consumption) towards the more specific trends that tie in closely to the topic of movies. According to this intention, we have collected literary sources and research data for review purposes, the following chapters disclose our findings.

\section{Effects of technological development}

Technological development has had a particularly significant impact on movie consumption, mainly in terms of accessibility, opening up the new dimensions of space-time. Consumers can now watch movies not only in their homes and movie theaters, but quasi anywhere, anytime with their portable electronic devices. Development and digitalization have left their mark on all varieties of movie watching. The vast majority of movie theaters replaced their traditional film projection machines with digital ones (starting 2013, all movie theaters in Budapest switched completely to using digital projection (Nyirö, 2013)); Efforts to achieve the highest possible picture and sound quality have become predominant in both movie theaters and homes; and since 2003, 3D technology has undergone significant development since its original introduction in 1922 (Zone, 2007) and became a major part of mainstream releases. In the case of the latter, the viewers can already distinguish between films that were originally shot in 3D (with specialized equipment and cameras) and those that were "improved" after the shooting was done in the studio (the same as they can notice the difference between different eras and technological solutions of $3 \mathrm{D}$ rendering).

As a countertrend, viewers who disapprove (or have negative attitude towards) of technological advances, are not looking for the latest display tools (be it televisions, projectors or even phones), or the highest picture and sound quality. In close relation to these groups, we can also see a (narrower) consumer segment that avoids 3D screening altogether (NMHH, 2020), or the increase in the number of visitors to Hungarian art cinemas. The latter often appearing as the preferred choice of movie goers even for non 'art' rated films (rather than their multiplex counterparts). Certain filmmakers also follow the trajectory of this countertrend (the likes of Christopher Nolan, Paul Thomas Anderson and Quentin Tarantino, to name a few) who reject the notion of transitioning into the digital systems and do not use digital cameras in their movies, and work exclusively on celluloid film.

\section{Experiences deemed evident}

It is a general consumer expectation to be entertained and enriched with experiences as viewers, all of which is deemed as a basic requirement. As part of the experience, the question of comfort must be highlighted, which has played a significant role in the relocation of the primary method of watching movies from the silver screen to the consumer homes. The transition to digital format can be mentioned in the same way, where there is no longer need to deal with physical media, which is even more extended by the interconnection of individual services with various advanced devices that ensure their continuous use. The latter include smart televisions, smart phones etc., all of which can be used to avoid even minor inconveniences such as searching for content with a television remote control (Lamkhede - Das, 2019). Opening up towards streaming content consumption has become particularly important in the wake of the COVID situation. In parallel with the partial or total shutdown of home 
theaters, the occurrence of watching movies at home has risen sharply, which has affected larger service providers as well. While Disney, for example, has postponed movies scheduled for 2021, Warner has taken its new releases straight to the screens available at home, with release dates matching the seemingly uncertain original theatric premieres (Alexander, 2020).

Before the appearance of the 2020 pandemic, we could witness such countertrend movements as "Let's go to the movies!", a series of events which aimed to have movie consumers return to the movie theaters from the comfort of their homes; or the various public film festivals or the occasional return of classic movies to the silver screen. Certain industry rulings were made under similar goals, such as taking a stand against digital-only distribution (where the distributors denied the theatrical release). One such example was the revamped regulations of the prestigious Academy Awards (The Oscars) where they stated that all contending movies must be screened in a movie theater (even if only for a short time and in a limited number of showings) which resulted in many service providers returning their releases to movie theaters (Bicsérdi, 2019). However, after the terrible results of 2020, and the ongoing restrictions remaining through 2021, it is not yet possible to see whether movie theaters will recover after the setbacks.

Movie theater visitor numbers are also affected by the experience evidence, especially when it comes to electronic ticket booking. As Kenesei and Kolos (2014) have pointed out in relation to general services, when it comes to booking systems, buying movie theater tickets is one of the most common association (along with airline and hotel room bookings). The systems of today often automate even the issuing of tickets, meaning there is no longer need to queue to receive a ticket, thus one may find it quick to acquire tickets with minimal human connection involved.

\section{Pace of life, the importance of saving time}

When it comes to saving time, there is a particular importance on the "right now trend", which may be attributed to the to the accelerated lifestyle of consumers (Töröcsik \& Szucs, 2002). According to this, consumers feel they do not have time to waste, they are not willing to wait around for anything, instead have a constant urge to satisfy their needs immediately. The same phenomenon was identified as a trend by Pulh et al. (2008), where immediacy was recognized as a leading factor in individuals' consumer behavior and may also aid them to live their lives with as little time wasted, as possible. For example, in addition to convenience, one of the strongest argument for the streaming services is that they significantly reduce search and decision time, through the employment of personalized recommendation systems. These systems might show highly accurate search results and recommendations based on the individual's previous choices and habits (Lamkhede \& Das, 2019). Another way they serve the immediacy is by the facilitation of 'binge watching', when the continuous watching of an otherwise serialized content may be conducted (Matrix, 2014; Mikos, 2016). While in the previous model, one had to wait a week (or more) between episode releases of such shows, digital providers often upload all episodes on a single premiere date, which allows viewers to set their own pace (even in a single, marathon-like session if they so choose). Previously, this was only possible for patient consumers who would wait for the full season of the series to finish (Flayelle et al., 2018). The accelerated pace of life may be found responsible for the movie advertising trends of recent years as well, where both teaser trailers and the extremely short (often 10-15 seconds) microtrailers (aimed for the shorter attention span of social media users) are gaining ground.

While Töröcsik (2011) recognized the temporary or permanent slowing down as the opposite of the accelerating pace of life, from a movie consumption point of view this countertrend realizes mainly in the occasional loss of interest towards new content. A common example being the cases when consumers have accumulated large reserves from unseen movies and shows of the past (a backlog of titles), resulting in a complete halt in searching for new releases until they have caught up.

\section{The power of communities}

Pulh et al. (2008) also pointed out the importance of community consumption as a substitute for individual consumption when examining the positioning possibilities of cultural institutions. Accordingly, many entities operating in the cultural market, such as movie theaters, prefer to place the community experience and joint movie 
watching at the center of their communication. Some examples being the aforementioned movie festivals, or even the sales promotion raffles which often offer double or group tickets as prizes. Interestingly, even the English term "going out" has roots in the social aspect, as it refers to the interaction of a shared cultural experience with others (Debenedetti, 2003).)

Based on the idea of supporting community movie watching, certain online opportunities have emerged as well, such as creating public movie lists; recommendations between users; the possibility to highlight on certain social media pages if one is watching a given movie. Furthermore there is an already available possibility for joint online movie watching, which helps even with the issue of physical distances.

The increasingly confusing genre classification of movies is also expected to fall into the hands of consumers, which due to the many variations and alterations grew quite challenging in recent years, apart from the most basic definitions (Varró, 2019). A glimpse of the possible future is provided by Steam, the number one online marketplace for computer video games, where a user-recommended keyword phrase system has been introduced a few years ago. The system allows users to use any word or phrase they deem appropriate to describe the available content, then the most popular (most common) terms will appear on the product page. As a result, consumers can systematically aid others' navigation and discovery on the platform (Windleharth et al., 2016).

The opposite trends of community based movie watching is primarily the act of watching movies alone (at home or on the go), which invokes many different effects on consumers. Typical examples are the individual (hidden) preferences, which often differ from the group based choices, such as the so-called "guilty pleasure" movies. These movies are generally widely considered to be of low quality (or are despised for some other reason) and are therefore rarely publicly accepted (McCoy \& Scarborough, 2014). As we have mentioned earlier, the COVID situation that boomed in 2020 have also significantly amplified this effect.

\section{Health- and environmental awareness}

Recent progress in health- and environment-conscious (and more economic) thinking can be seen in the field of out-of-home movie theater offerings. The efforts made by governments (realized through taxes and legislation (Szöllösi \& Róbert, 2012)) to reduce unhealthy food led to many movie theaters narrowing their offerings of snacks, but a similar measure may be seen through the increased use of degradable and recyclable materials. Be it soda glasses or popcorn bags, more and more places are introducing environmentally friendly alternatives to plastics. Most movie theaters also urge their visitors to keep and reuse the 3D glasses they received to watch 3D movie screenings.

As a opposed to the healthy lifestyle, the lack of movement should be highlighted as a countertrend, which may also be significant in the case of films, and especially binge-able shows, as they can easily compel the viewers to be still for a longer period of time. Also worth mentioning is that even with the aforementioned regulating and push for healthier offerings, the prevalent snack choices of movie goers still consist primarily of unhealthy foods with low nutritional value (a leading culprit being popcorn, which for many is completely intertwined with the movie-watching experience).

\section{Fragmented information}

Lack of information and knowledge usually appears as a negative feature for most industries, but in the case of movies, this trend is often the result of conscious and even necessary decisions. Filmmakers want to limit both the amount of information unintentionally omitted from the film (script content, filming information, images and videos) and the information content of intentional communication (the contents of trailers, scenes snatched from the film as preview, interviews), as they are trying to avoid revealing too much from the movie. However, despite all such efforts, even in the case of carefully compiled film trailers, there is often criticism that they have been shown too much in advance.

Filmmakers take quite astonishing precautions for complete secrecy: Quentin Tarantino, for example, forbid the use of any smartphones during the filming of Once upon a time in Hollywood, all the while he made only one copy of the complete screenplay (containing every scene and dialogue), which was locked in a safe in his house 
(Torres, 2018). Similar cautiousness was witnessed by the creators of the Hungarian-language dub of The Lord of the Rings movies, when they received a fully censored version of the movies, where they could only see the moving mouths of actors, which they had to use synchronize properly (Nevelös, 2013). Meanwhile, consumers also often actively try to avoid getting to know too many details: film recommendations (whether from an acquaintance or even a professional critic) are expected to be free of spoilers (premature disclosure of the film's plot and twists).

The countertrend consists mainly of consumers who are specifically hunting for all forms of information before the release of a title. Looking through interviews with cast and crew for accidental slips, seeking out news of leaks from the production phase, collecting the work in progress footages to gather any and all available information. Often separate forums are set up to collect and organize these, and all of this is often incorporated into fan discourses and theorizing that precede the release of a movie (Ford, 2014).

\section{Knowledge gap}

The knowledge gap between individual consumers can often be tremendous, which in terms of proficiency in the digital world, can be especially significant for films. In practice, the knowledge-based "omnivorous" type of cultural consumption theory can be matched by consumers who are well-informed in the digital space. They are confident in what features to look for, what pitfalls to avoid, when they are searching for access to contents, like movies or series. To overcome the technological limitations of digital procurement is especially important for navigating through the illegal methods of obtaining content, but often even the legal content acquisition requires a certain level of familiarity. One has to have a basic understanding of the different formats and quality indicators available: to name a single aspect (out of many) of image quality for example, the indicators of SD (480p), HD Ready (720p), FHD (1080p), Quad HD (1440p), UHD (2160p), 8K (4320p) content may be trivial for many but many will just feel confused among the numerous resolution types and differences. All the while other technical differences, such as the aspect ratio, compression method, image and audio transmission etc. could all be cited in the same way.

The primary countertrend is presented by the consumer segment that is unwilling to deal with the abovementioned technological aspects, their only requirement for watching movies is the question of convenience. To appease their satisfaction, it is especially important to have as many comprehensive, facilitating solutions as possible that simplify the act of watching movies. These include localizing and simplifying the menu system on purchased physical media; localization and/or pre-installation of applications for streaming services on newly purchased devices; or the availability of localized content search (how the search engine deals with special characters for example).

Certain movies and series with more complex, twisted story arcs are also based on the trend of the knowledge gap, as they requires the viewer's full attention and thinking. In contrast, we can also find an interesting contrast in certain simplified content, which do not provoke the viewer for active thinking, and instead has "mindless fun" as its main allure (such as a significant portion of the 20-minute format, mainly light-hearted comedies). Their driving force relies on the more passive form of entertainment, while they also support content consumption where only a portion of attention is available (Sprenger, 2009; Saxena et al., 2017).

\section{Importance of visuality}

The trend of visuality and saturated "information dumping" can be seen primarily in the promotion of films. Through the movie trailers, often a condensed version of the whole plot of the film can be seen, in which they try to introduce the main plot elements, the mood and the prevailing emotions, all in just a few minutes. The trend of visuality is also followed by the sensory approach of cultural experience to goods (Holbrook \& Hirschman, 1982; Pulh et al., 2008). Similarly, visual representation plays a major role in the growing budget of so-called summer blockbuster movies, where the studios are trying to one-up each other annually, at least in terms of visuals and image quality.

Meanwhile, audiences have share a growing confidence in the low-budget projects that have been rising in recent years, often produced independently from large studios, which has from time to time resulted in quite astonishing 
return of investment. For example, the 2007 made minimalist horror, Paranormal Activitiy, which was originally shot with just small crew and a couple of cameras, has generated 107 million USD in revenue in the U.S. alone, while the filming costs were 15,000 USD (Hahner et al. 2013). Similarly aiming towards minimalism, the Dogme 95 movement was spearheaded in 1995 by Danish director, Lars von Trier, which tried to stand firm against predictable dramaturgy, superficial actions, and technological image enhancement (Schepelern, 2005).

Another countertrend to the visualization aspect is the popularity of such viewer aspirations where by reversing the roles, they take control and create alternative versions of different films. Examples include the low budget, so-called "sweded" movies (with the term originating from the movie, Be kind, rewind), that are short reinterpretations of already existing films, with certain limitations set on the production, such as using only camera tricks, hand-made props and human made sounds as special effects (Junkerjürgen, 2013). In a similar vein we can see a community effort to completely reverse additions of the 1997 special edition release of Star Wars' original trilogy by removing all scenes and visual effects that were not included in the original releases. Thus attempting to restore the appearance of films originally shown between 1977 and 1983, which is otherwise not commercially available (Miller, 2015).

\section{Emphasis on women}

As Törőcsik (2011) has pointed it out, more and more women around the world are taking up work and studying, and overall, their economic power and advocacy capacity is constantly increasing. This trend is particularly evident on the consumer side, where, according to the statistics released by the Motion Picture Association of America (MPAA), there is a roughly equal proportion of men and women attending movie theaters (MPAA, 2018), all the while we can see an increasing number of women-centric (that are still diverse in genre) movies and series being created that are intended for specifically for women audiences as a target market.

Meanwhile, examining films in general Smith et al. (2018) has highlighted significant inequalities. For example, in the case of the highest grossing American made movies in recent years, the proportion of women actors appearing in a speaking roles has changed little since 2007 (which may be seen on Figure 1).

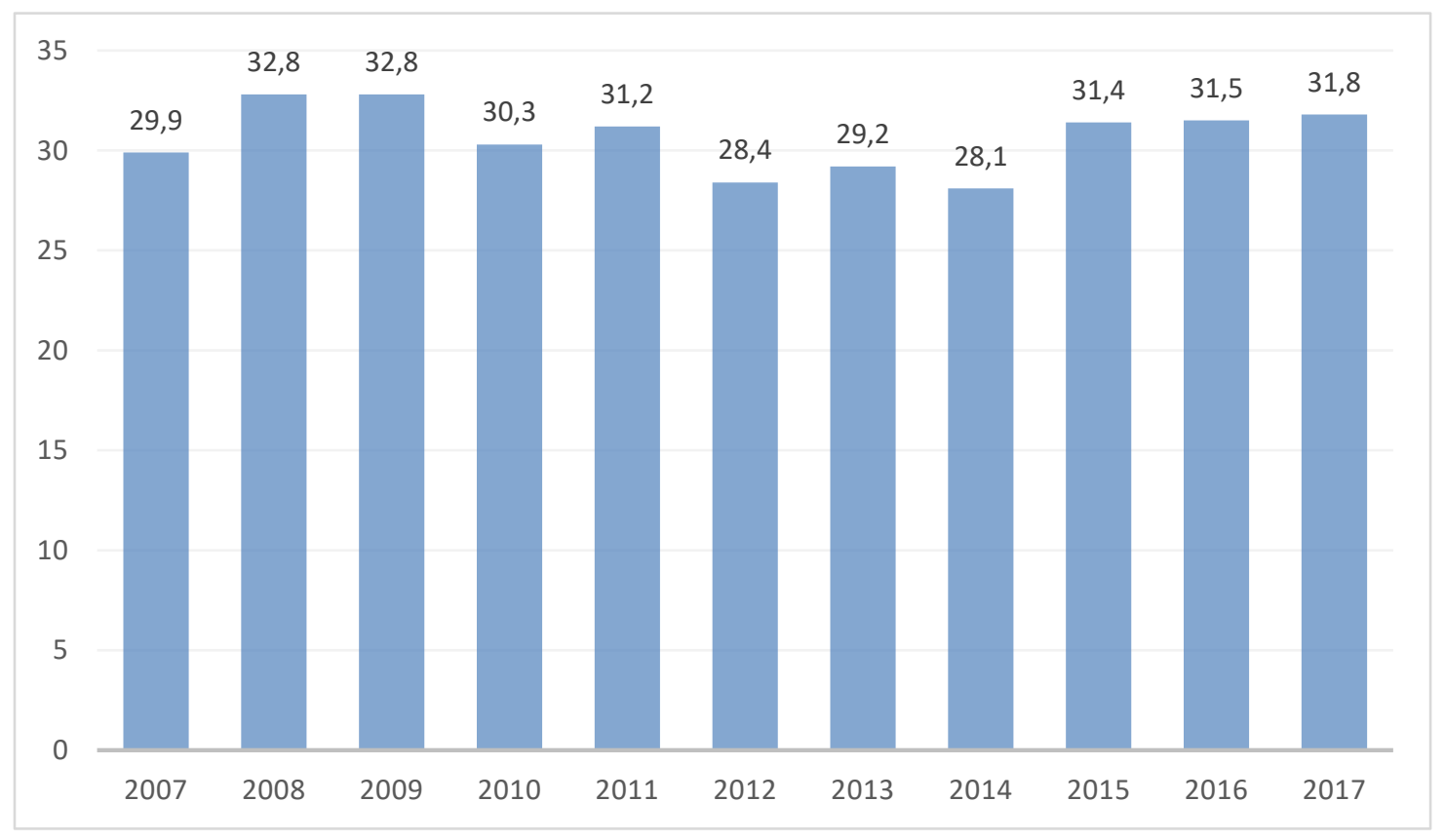

Figure 1. Prevalence of female speaking characters between 2007-2017 in percentages

Source: Own elaboration (2021) based on Smith et al. (2018). 
Similarly, the proportion of women filmmakers is relatively low as well: for the movies produced in the year 2017, the research has shown that from the 1584 titles analyzed, only 18,2\% included women professionals with directorial, writer or producer credit (taking only the directors into account, the percentage drops even further to 7,3\%).

\section{Film tourism}

Movie induced tourism may often be seen as a unique blend of merchandising and product placement. Roesch (2009) interprets it as a branch of tourism in which visitors visit locations seen in films or series - sometimes even during the production. The reason for this phenomenon is that films can create a strong emotional connection with the locations seen on the screen. Thanks to the interest generated by movies and series, venues can benefit greatly from increased traffic even years or decades after the film's release (like New-Zealand using The Lord of the Rings movies as promotional tools to this day).

In his work, Roesch (2009) distinguished between locations (countries, settlements, general spaces) presented on the screen from actual filming locations (the former not always depicting locations that are approachable in the real world). The latter can be further subdivided into on-location tourism and the artificial off-location tourism, which mainly consists of movie studio tours, amusement parks and other events (like movie related festivals and galas).

Early research on movie induced tourism that examined the motivations of visitors to movie related locations, highlighted the passive, and thus more superficial movie watching which they reflected onto their motivations as well. However, this interpretation has been replaced over time by the more complex, personality-based motivation theories (Macionis, 2004; Beeton, 2006). Irimiás (2015) identified the following possible types of tourists in relation to movies: chance based movie tourists (who found themselves at the location associated with the film, although their decisions were not influenced at all by the film connection), general movie tourists (for whom the movie aspects appeared among other motivating factors, but was not the primary decision-making aspect) and dedicated movie tourists (who specifically seek out and visit the locations seen in the movies).

\section{Popular genres as trends}

In the case of movie consumption trends, the ever-changing interests in the various genres should also be emphasized, which may be traced alongside the changes in consumer needs. While certain movie genres have crystallized in the past century under the basis of a rough cultural selection. Over this course the standard characteristics of each genre has been formed and clarified on the basis of the viewers' expectations. With the appearance of countless variations and subgenres however, film genres themselves have since undergone many changes (aided by the occasional bursts of single titles with unique features that confronted the aforementioned expectations), but they have retained their unique key-characteristics throughout (Varró, 2019).

While comedy is a genre that is generally stable over time, other genres face constant changes in their popularity as interest increases or decreases over the years. The major changes to interest were often driven by other significant historic events of the age, such as the increase in the number of war films produced during the Second World War. In many cases, more topical interest may be observed, such variations often fall under general genres. The last decade of action films, for example, has been characterized by comic book adaptations (which, with their outstanding revenues, will certainly have a significant impact on the action film genre in the coming decade (Rauscher 2010, Nielsen, 2017)). We can perceive the nearly 40-year gap between 1930 and 1970 as the golden age of musicals, which was based on the surge of adaptations of various Broadway plays, as well as popular music and dance oriented movies, such as the 1952 release of Singin' in the Rain. Out of the often related, cooperating pair of crime and thriller (Varró, 2019), we can say that nowadays the thriller side eventually became the more dominant genre. In the wake of themed television channels, documentaries have also gained significant momentum, which was further aided by the assorted and easily accessible quality document series offered by streaming service providers (De Rosa \& Burgess, 2014). 


\section{Conclusions, limitations}

The main purpose of the study was to explore and describe the main trends of cultural consumption on the field of movie consumption (and related behavior) as well as the emerging countertrends. In doing so, we examined the generally accepted trends (of different scale) in consumer behavior that could be interpreted in the light of movies as unique service products. In addition, we examined two trends that are even more focused in their movie orientation: the phenomenon of movie induced tourism and the development of trends in movie genres. These two are special in the sense, that they could not be interpreted outside the environment of movies. Meanwhile in the interpretation of each trend, their countertrends have also played an important role.

Among the trends and counter-trends gathered in the study, there is a steady increase in the importance of home (and other alternative) movie watching over movie theaters. As better quality methods and devices to watch movies in the home environment (and on consumer portable devices) are becoming available, we can see the superiority of the more convenient, simpler, and more accessible streaming providers in more and more related trends. This mentality is not only reflected by the trends, but is also in line with other separate researches aimed at younger generations, where we can see that the emphasis is gradually placed on offers that are both easily accessible and also able to serve specific interests (for which they must carry a wide spectrum of available content).

The emergence of these consumer trends and special demands have begun years ago, but due to the COVID situation, its previous slow rise turned into a rapid acceleration: while digital content providers and the movie producing companies themselves shifted relatively smoothly (or increased their capacity) towards new broadcasting models, brick and mortar movie theaters have had their operations halted in such a manner that their resumption after the pandemic also became uncertain.

The study has no primary research, so it may be considered mainly as a literature review, as all of the data used and presented were from external sources. In describing these sources, we tried to explore the connections that are significant in an international level regarding to the trends of movie consumption. In the future, we also plan to investigate the field of movie consumption in targeted primary research, with special regard to the opportunities offered by digital content providers.

Funding: self-funded.

Author contribution: conceptualization, Horváth Ádám, Gyenge Balázs; data curation, Horváth Ádám; formal analysis, Horváth Ádám; funding acquisition, Horváth Ádám, Gyenge Balázs; investigation, Horváth Ádám, Gyenge Balázs; methodology, Horváth Ádám, Gyenge Balázs; project administration, Horváth Ádám, Gyenge Balázs; resources, Horváth Ádám, Gyenge Balázs; software, Horváth Ádám; supervision, Horváth Ádám, Gyenge Balázs; validation, Horváth Ádám, Gyenge Balázs; visualization, Horváth Ádám; writing - original draft, Horváth Ádám; writing - review \& editing, Horváth Ádám.

\section{References}

1. Alexander, J. (2020). Warner Bros. will release all of its new 2021 movies simultaneously on HBO Max. The Verge, 2020 December. Available at: https://www.theverge.com/2020/12/3/22150605/hbo-max-warner-brosmovies-2021-simultaneous-release-matrix-godzilla-suicide-squad-space-jam Accessed 2021.01.27.

2. Beeton, S. (2006). Understanding Film-Induced Tourism. Tourism Analysis, 11, 181-188 DOI: $10.3727 / 108354206778689808$.

3. Bicsérdi, Á. (2019). Lesz magyarországi mozis bemutatója 3 Netflix-filmnek is. Kreatív Online [There will also be a screening of 3 Netflix films in Hungarian cinema. Creative Online]. Available at: http://kreativ.hu/cikk/megis_lesz_mozis_vetites_3_netflix_filmbol_is_itthon Accessed 2020.12.18.

4. De Rosa, M. \& Burgess, M. (2014): Learning from documentary audiences: A market research study. Ontario Media Development Corporation, Ontario. p. 5-9. Available at: http://s3.amazonaws.com/assets.hotdocs.ca/doc/Hot_Docs_Learning_from_Documentary_Audiences.PDF. 
5. Debenedetti, S. (2003): Investigating the Role of Companions in the Art Museum Experience. International Journal of Arts Management, 5(3), 52-63. Available at: https://www.researchgate.net/publication/41220233 Investigating the Role of Companions in the Art Museum Experience.

6. Flayelle, M., Maurage, P., Vögele, C., Karila, L., Billieux, J. (2019). Time for a plot twist: Beyond confirmatory approaches to binge-watching research. Psychology of Popular Media Culture, 8(3), 309-318. DOI: $10.1037 / \mathrm{ppm} 0000187$.

7. Ford, G. S. (2014). Movie Leaks, Box Office Success and Child's Play: An On-Line Game Is No Way to Measure Piracy. Phoenix Center Perspective, No. 14-07. Available at: https://www.prnewswire.com/newsreleases/phoenix-center-finds-movie-piracy-remains-a-serious-problem-280642072.html.

8. Hahner, L. A., Varda S. J., Wilson N. A. (2013). Paranormal activity and the Horror of Abject Consumption. Critical Studies in Media Communication, 30(5), 362-376 DOI: 10.1080/15295036.2012.690523.

9. Holbrook M. B. \& Hirschman E. C. (1982). The Experiential Aspects of Consumption: Consumer Fantasies, Feelings, and Fun. Journal of Consumer Research, 9 (2), 132-140. DOI: 10.1086/208906.

10. Irimiás, A. (2015). Filmturizmus. Akadémiai Kiadó [Film tourism. Academic Publisher], Budapest. p. 235. DOI: $10.1556 / 9789630598767$.

11. Junkerjürgen, R. (2013). «... not just simple remakes». Sweded Movies als Filmtravestien. Zeitschrift für Medienwissenschaft, $8(1), \quad$ 156-164. Available at: https://mediarep.org/bitstream/handle/doc/2453/ZfM 08 156164 Junkerjuergen_Sweded_Movies_pdf?sequence $=7$.

12. Kenesei, Zs. \& Kolos, K. (2014). Szolgáltatásmarketing és -menedzsment. Alinea Kiadó [Service marketing and management. Alinea Publisher], Budapest, p. 218-220, 350. Available at: https://docplayer.hu/158473720-Ii-zalaegerszegi-egeszsegturizmus-konferencia-tanulmanykotet.html.

13. Lamkhede, S. \& Das, S. (2019). Challenges in Search on Streaming Services: Netflix Case Study. In: Proceedings of the 42nd International ACM SIGIR Conference on Research and Development in Information Retrieval. ACM, New York NY. p. 1371-1374 doi: 10.1145/3331184.3331440.

14. Macionis, N. (2004). Understanding the film-induced tourist. In: Frost, W., Croy, G., Beeton, S. (Ed.): International Tourism and Media Conference Proceedings. Monash University Tourism Research Unit, Berwick. $\quad$ p. 86-97. Available at: https://www.academia.edu/3378880/Understanding the film induced tourist.

15. Pulh, M., Marteaux, S., Mencarelli, R. (2008). Positioning Strategies of Cultural Institutions: A Renewal of the Offer in the Face of Shifting Consumer Trends. International Journal of Arts Management, 10(3), p. 416. Available

https://www.researchgate.net/publication/278762122_Positioning_Strategies_of_Cultural_Institutions_A_R enewal_of_the_Offer_in_the_Face_of_Shifting_Consumer_Trends.

16. Matrix, S. (2014). The Netflix effect: Teens, binge watching, and on-demand digital media trends. Jeunesse: Young People, Texts, Cultures, 6(1), 119-138. DOI: 10.1353/jeu.2014.0002

17. McCoy, C. A. \& Scarborough, R. C. (2014). Watching „bad” television: Ironic consumption, camp, and guilty pleasures. Poetics, 47, 83-105. DOI: 10.1016/j.poetic.2014.10.003

18. Mikos, L. (2016). Digital Media Platforms and the Use of TV Content: Binge Watching and Video-onDemand in Germany. Media and Communication, 4(3), 154-161. DOI: 10.17645/mac.v4i3.542

19. Miller, D. (2015). Restoring Star Wars. Australian Broadcasting Corporation, 2015 December. Available at: https://www.abc.net.au/news/2015-12-14/restoring-star-wars/6994818. Accessed: 2021.01.13.

20. MPAA (2018). Theme Report. The Motion Picture Association of America. Available at: https://www.motionpictures.org/wp-content/uploads/2019/03/MPAA-THEME-Report-2018.pdf. Accessed: 2021.01.17.

21. Nevelős, Z. (2013). Magyar hangja - Szinkronkészítők régen és most [Hungarian Voice - Synchronous Creators of the Past and the Now]. Filmvilág, 56(9), 28-31. Available at: https://filmvilag.hu/xista_frame.php?cikk_id=11542.

22. Nielsen, L. (2017). Marvel Films As Effective Cinema Therapy. Cinesthesia, 7(1), 3. Available at: https://core.ac.uk/download/pdf/220123224.pdf. 
23. NMHH (2020). Negyedéves Moziforgalmi statisztikai adatlapok és ,art” mozi statisztikai adatok. Nemzeti Média- és Hírközlési Hatóság [Quarterly cinema statistics and "art" cinema statistics. National Media and Communications Authority], Budapest. Available at: https://nmhh.hu/nemzeti-filmiroda/mozgokepstatisztika.

24. Nyírő, N. (2013). A mozi. In: Horváth, D - Nyirö, N. - Csordás, T. (Szerk.). Médiaismeret - Reklámeszközök és reklámhordozók [Media literacy - Advertising media and advertising media]. Akadémiai Kiadó, Budapest. p. 155-174. Available at: https://mersz.hu/dokumentum/dj151m_1.

25. Rauscher, A. (2010). The Marvel Universe on Screen: A New Wave of Superhero Movies? In: Berniger, M., Ecke, J., Haberkorn, G. (Ed.): Comics as a Nexus of Cultures: Essays on the Interplay of Media, Disciplines and International Perspectives. McFarland \& Company, Jefferson, NC. p. 21-32. https://searchworks.stanford.edu/view/8578413.

26. Roesch, S. (2009). The experiences of film location tourists. Channel View Publications, Bristol. DOI: $\underline{10.21832 / 9781845411220 .}$

27. Saxena, R., Bhat, S., \& Pedanekar, N. (2017). Live on TV, Alive on Twitter: Quantifying Continuous Partial Attention of Viewers During Live Television Telecasts. 2017 IEEE International Conference on Data Mining Workshops (ICDMW), pp. 1042-1049. DOI: 10.1109/ICDMW.2017.147.

28. Schepelern, P. (2005). Film according to Dogma: ground rules, obstacles, and liberations. Transnational Cinema in a Global North: Nordic Cinema in Transition, 73-107. Available at: https://comm.ku.dk/staff/?pure=en\%2Fpublications\%2Ffilm-according-to-dogma(4b05fd10-74c3-11dbbee9-02004c4f4f50)\%2Fexport.html.

29. Smith, S. L., Choueiti, M., Pieper, K., Case, A., Choi, A. (2018). Inequality in 1,100 Popular Films: Examining Portrayals of Gender, Race/Ethnicity, LGBT \& Disability from 2007 to 2017. Annenberg Inclusion Initiative. Available at: http://assets.uscannenberg.org/docs/inequality-in-1100-popular-films.pdf. Accessed 2020.12.17.

30. Sprenger, M. (2009). Growing Up Connected. Teaching for the 21st Century, 67(1), 34-39. Available at: https://www.d11.org/cms/lib/CO02201641/Centricity/Domain/547/Focusing\%20the\%20Digital\%20Brain\%20S eptember\%202009.pdf.

31. Szőllősi, S., \& Róbert, S. S. (2012). A Népegészségügyi termékdíj 2011-ben és 2012-ben [The Public Health Product Award in 2011 and 2012]. Economica, 5(1), 40-47. Available at: https://dtk.tankonyvtar.hu/xmlui/handle/123456789/4111.

32. Törőcsik, M. (2011). Fogyasztói magatartás, insight, trendek, vásárlók [Consumer behavior, insight, trends, customers]. Akadémiai Kiadó, Budapest, pp. 35-58, 375-377. Available at: https://mersz.hu/dokumentum/dj72fm_1.

33. Törőcsik, M., Szücs, K. (2002). Az új fogyasztói szegmensek - az e-ember [New consumer segments - the eman]. Marketing és menedzsment, 36(2), 64-70. Available at: https://journals.lib.pte.hu/index.php/mm/article/view/1590.

34. Torres, L. (2019). 8 things you didn't know about the filming of 'Once Upon a Time in Hollywood'. Insider, 2019 august. Available at: https://www.insider.com/once-upon-a-time-in-hollywood-behind-the-scenes2019-8. Accessed: 2021.01.18.

35. Varró, A. (2019). Az önző mémek (Zsánerfilmek tipológiája). [Selfish memes (Typology of genre films)]. Filmvilág, 62(9), 24-31. Available at: https://filmvilag.hu/xereses talalatok c.php?kereses tipus=reszletes\&rovat=M\%FBfajok+\%E9s+m\%E9mek.

36. Windleharth, T. W., Jett, J., Schmalz, M., Lee, J. H. (2016). Full Steam Ahead: A Conceptual Analysis of User-Supplied Tags on Steam. Cataloging \& Classification Quarterly, 54(7), 418-441. DOI: 10.1080/01639374.2016.1190951.

37. Zone, R. (2007). Stereoscopic cinema and the origins of 3-D film, 1838-1952. University Press of Kentucky, Lexington, KY. p. 1-5. DOI: 10.5810/kentucky/9780813124612.001.0001. 